\title{
Post-Conflict Justice and Sustainable Peace
}

\author{
Tove Grete Lie, Helga Malmin Binningsbø, and Scott Gates
}

\author{
Centre for the Study of Civil War, PRIO \\ and \\ Norwegian University of Science \& Technology (NTNU)
}

\begin{abstract}
No systematic study has examined the effect of post-conflict justice on the duration of peace on a global basis. This paper attempts to fill that void by building on a newly constructed dataset (Binningsbø, Elster \& Gates, 2005), which reports the presence of various forms of post-conflict justice efforts (trials, purges, reparation to victims, and truth commissions) as well as processes associated with abstaining from postconflict justice (amnesty and exile). The long-term effects of post-conflict justice on the duration of peace after conflict are investigated. A Cox proportional hazard model is used to analyze the influence of the various types of post-conflict justice on the length of the peace period before the recurrence of violent conflict. Post-conflict trials as well as other types of justice do lead to a more durable peace in democratic as well as non-democratic societies, but the results are weak and are therefore difficult to generalize. Forms of non-retributive justice (i.e. reparations to victims and truth commissions), however, are strongly associated with the duration of peace in democratic societies, but are not significant for non-democratic societies. Amnesty tends to be de-stabilizing and generally associated with shorter peace duration, but exile tends to lead to a more durable peace.
\end{abstract}

World Bank Policy Research Working Paper 4191, April 2007

The Post-Conflict Transitions Working Paper Series disseminates the findings of work in progress to encourage the exchange of ideas about post-conflict development (more information about the Post-Conflict Transitions Project can be found at http://econ.worldbank.org/programs/conflict). An objective of the series is to get the findings out quickly, even if the presentations are less than fully polished. The papers carry the names of the authors and should be cited accordingly. The findings, interpretations, and conclusions expressed in these papers are entirely those of the authors. They do not necessarily represent the views of the World Bank, its Executive Directors, or the countries they represent. Policy Research Working Papers are available online at http://econ.worldbank.org . 


\section{Facing the Peace versus Justice Dilemma}

As part of the ongoing peace process, the Colombian Congress in June 2005 approved a law intended to demobilize right-wing paramilitary fighters by granting reduced jail terms and other benefits. The law was successful, as approximately 22,000 paramilitary fighters have handed in their weapons in exchange for the law's promise of a monthly stipend of about $\$ 180$ and amnesty from prosecution for rebellion and minor crimes (Goodman 2006). The law has, however, been severely criticized by human rights activists, as it paves the way for thousands of paramilitary fighters - whose war against left-wing guerillas has included massacres, disappearances and expulsion of several thousand suspected guerilla supporters (Dudley 2006). As expressed by Amnesty International’s secretary general Irene Kahn:

"The Justice and Peace Law is deeply flawed and will only serve to strengthen the already chronic problem of impunity in Colombia...The law fails to respect victims' right to truth, justice and reparation.” (Molinski, 2005)

The above discussion regarding the Colombian peace process is an excellent example of a dilemma faced by a number of politicians and peace mediators also concerned with human rights and international law. As reflected in the UN charter, the general international consensus appears to be that those responsible for gross human rights violations should be held accountable, regardless of whether the atrocities take place during war or peace time. A number of authors argue that the international community does, under international treaties and customary law, have an obligation to bring perpetrators of war-crimes to justice (Othman 2005, Bass 2005, Shraga 2004). These moral and legal arguments are often supported by psychological as well as political rationales for post-conflict accountability. Psychologically, justice is necessary to heal traumas and old wounds, which is needed to reach reconciliation and peace (e.g. Mani 2002, Long \& Brecke 2003). Politically, a failure to carry out justice may undermine the legitimacy of the postconflict government and encourage future violence (e.g. Mani 2002, Elster 2004, Gloppen 2005).

Despite strong arguments in favor of post-conflict justice (PCJ), some researchers and politicians view PCJ as a phenomenon that should be compromised for the sake of peace. The argument is that rebels will be unlikely to lay down their weapons and stop fighting if they fear post-war prosecution (Aron 1981, Huntington 1993, Fearon 2005). Post-conflict amnesty and exile, which make perpetrators immune to post-conflict prosecution, may therefore be granted to 
buy off rebels and prevent them from perpetrating future violence. This, together with the fact that post-conflict societies often lack the institutional and economic means to carry out fair and impartial justice without compromising other aspects of peace building, creates doubts about the practical value of PCJ in the crafting of post-conflict peace and stability. A lack of systematic empirical research regarding the effect of PCJ on peace combined with mixed findings in a number of case-studies exemplifying the process of justice in one or two post-conflict societies at a time (e.g. Pinto 2001, Aguilar 2001, Reyntjens \& Vadenginste 2004, Skaar 2004), contribute further to the ongoing debate. ${ }^{1}$

For our examination of the effects of PCJ on the prospects for post-conflict peace and stability, we focus on 'what works' rather than what is morally or legally appropriate. In doing so, we rely on a recently collected dataset from Binningsbø, Elster \& Gates, (2005), reporting the presence of various forms of PCJ (trials, purges, reparations to victims, and truth commissions), as well as processes commonly associated with post-conflict impunity (amnesty, exile), in the aftermath of each conflict, 1946-2003, present in the Uppsala-PRIO Conflict Data Base (Gleditsch et al. 2002). The Binningsbø, Elster \& Gates (2005) dataset is one of the first attempts to systematically collect information on post-conflict justice on a global scale. ${ }^{2}$ Consequently, it offers a unique opportunity to quantitatively investigate the influence of PCJ in a variety of situations, complementing previous case studies of post-conflict justice.

When focusing on PCJ in post-conflict settings, we are aware that we compromise the concept of justice or legal justice (Elster, 2004), as justice is associated with being fair and impartial. ${ }^{3}$ Note that trials and purges, in particular, may more correctly be described as winners justice (e.g. Minnow 1998, Gloppen 2005) or political justice (Elster 2004), directed at the conflict's losing party, with the intention of repression and deterrence rather than forgiveness and reconciliation. Also keep in mind that these processes mostly pertain to what Mani (2002: 7-8) refers to as rectificatory justice, dealing with injustice in terms of direct physical violence suffered by people during conflict. This is not distributive justice, which entails addressing the underlying cause of conflict, such as social, political or cultural injustice. The absence of

\footnotetext{
${ }^{1}$ An exception to the case-study framework is the comparative study of Long \& Brecke (2003).

${ }^{2}$ Sikkink \& Wallin (2005) present a data set on trials and truth commissions in 192 countries. However, they do not investigate as many efforts as Binningsbø, Elster \& Gates (2005), and their primary focus is not on post-conflict sustainable peace.

${ }^{3}$ Elster (2004: 135-139) describes legal justice as justice based on unambiguous laws, a judiciary insulated from other branches of government, unbiased judges and jurors, and an adherence to the principles of due processes.
} 
organized violence is, according to Galtung (1985), a minimalist definition of peace, which is different from a situation of structural or cultural peace where the underlying cause of conflict would also be removed. A minimalist definition of peace does not require that structural injustice is addressed or that peace is based on reconciliation rather than repression and deterrence. We use such a minimalist definition of peace.

Since the purpose of justice and other means of dealing with past atrocities may contrast sharply in the context of an autocracy and a democracy, we distinguish between these two postconflict settings. ${ }^{4}$

Since we are interested in the duration of peace in post-conflict societies, we investigate the influence of transitional justice by relying on event history analysis. Event history or survival analysis allows us to model the effect of transitional justice on the duration of peace before a new conflict eventually erupts while simultaneously controlling for other factors, such as type of settlement, length of conflict, regime characteristics, and other factors that do possibly contribute to peace and stability. Before discussing the specifics of our model, we discuss how and why we expect retributive as well as non-retributive post-conflict justice to prolong the post-conflict peace period. Our general proposition is that PCJ, manifested in terms of either legal or political justice, will contribute to more sustainable post-conflict peace, but we note that there are many problems associated with carrying out justice in a post-conflict setting, and that the fear of post-conflict prosecution on occasions may undermine a peace process. We therefore want to emphasize that this paper, in many ways, is a first cut, posing some preliminary propositions and testing them with some new data. We elaborate more on the various types of transitional justice below and discuss how they may eventually contribute to post-conflict peace duration.

\section{Retributive Post-Conflict Justice and Sustainable Peace}

Retributive justice is the type of justice that has received the most attention in post-conflict situations ${ }^{5}$-- much to the distress of those most skeptical toward PCJ, many of whom would rather see greater focus on distributive justice. Retributive justice emphasizes the need to hold perpetrators accountable and to be punished for their crimes. The institutional mechanisms for

\footnotetext{
${ }^{4}$ For researchers working within the transitional justice tradition, post-conflict justice is presumed to take place in a democratic setting. We distinguish between democratic and non-democratic settings, and find it critical to our analysis.

${ }^{5}$ Indeed, retributive justice also dominates in works on transitional justice (i.e. justice in the context of democratization) as well.
} 
carrying out such justice include prosecution and sentencing in domestic courts and special tribunals, in international tribunals, in joint international and domestic tribunals, or in foreign courts. Lustration, administrative procedures used to lock perpetrators and collaborators out of jobs and positions as well as expose them to public scrutiny and social shaming, is a weaker measure also falling into this category (Nalepa 2006; Gloppen 2005: 18). In post-conflict democratic settings these mechanisms are more likely to be carried out as part of the reconciliation process and as a response to humanitarian rights principles. In autocratic settings they are more arbitrary and usually directed toward the losing side of the conflict, such as separatist rebels, failed coup-makers, or leaders of the previous regime. In these situations, trials often take place as show-trials where the outcome is known prior to the legal process (Elster 2004). There are, however, psychological as well as political reasons to believe that post-conflict retributive justice, either legal justice or show trials, may have a peace-bringing effect that goes beyond the legal and moral aspect of war-crime punishment.

The psychological rationale for retributive post-conflict justice stems from the need to understand and heal the trauma of victims and survivors of conflict. Civil wars by definition involve victims, regardless of the purpose or mission of the belligerents. ${ }^{6}$ According to Bass (2005: 3) there is little doubt that victims desperately want to see some kind of punishment for those that have destroyed their life or killed their loved ones making amnesty an incomplete and unacceptable solution. Holding perpetrators responsible for gross human rights violations, genocide, ethnic cleansing, torture and other types of war-crime, can be important for those affected by these crimes, enabling them to attain closure and restore healthy relations toward one another (Gloppen 2005: 22).

The psychological effects of post-conflict justice on peace and reconciliation are, however, disputed. Some have suggested that PCJ may, in fact, create greater resentment among former participants to civil conflict, opening old wounds and inflicting new ones in already fragmented societies (e.g. Long \& Brecke 2003: 68), while others (e.g. Stover 2005; Stover \& Weinstein 2005) find both international and local trials to have very limited effect on victims' attitudes toward the enemy. Others, such as Fletcher \& Weinstein (2002) have suggested that trials lead to an individualization of guilt that reduces the collective incentive for forgiveness. But

\footnotetext{
${ }^{6}$ Armed conflicts in the Uppsala-PRIO dataset, by definition, involve at least 25 battle related deaths and a non-state actor in opposition to representatives of the state.
} 
perhaps most important, to explain long-term peace and reconciliation, one needs to identify the mechanisms that can transfer the individual psychological and cognitive effects of post-conflict prosecution into political consolidation.

For those affected by past atrocities, post-conflict retribution can serve to demonstrate a break with the immoral order of the past and help to build trust in the new social order (Gloppen 2005). Failing to deal with past atrocities, in contrast, may reduce the government's legitimacy, preventing it from stabilizing the situation (Elster 2005). If conflict constitutes a transformation from one regime to another, a public process directed against the previous regime holders may also have the effect of depriving the legitimacy and prestige of the previous elites and discrediting their ideology (de Brito, Gonzalez-Enriquez \& Aguilar 2001: 313).

Furthermore, a number of scholars stress the importance of public retributive justice in the protection against a cycle of revenge attacks (e.g. Elster, 2004, 2005, Pankhurst 1999, Bass, 2005). If victims of war as well as previous dictatorship feel that wrongdoings are not sufficiently dealt with by legal processes they may be tempted to carry out private justice toward other individuals, which can be seen as a substitute, or pre-emption, for legal justice (Elster, 2004: 153). As explained by Elster (2005: 10), immunity of the insurgents creates the danger of wild justice, or spontaneous revenge by one side that the other side will see as an attempt to initiate another civil war.

Moreover, post-conflict trials ensure perpetrators or insurgents are put away, at least for a period of time, so that they cannot launch a new insurgency once the conditions seem appropriate (Elster 2005: 8). As expressed by Pankhurst (1999) attempts to mete out justice for past crimes may increase the chances for peace in the longer term because they exclude from positions of power perpetrators that might have their own reasons for prolonging or renewing the conflict. In these respects, the prosecution of perpetrators may have an effect on post-conflict peace duration in autocratic as well as democratic regimes. We make the following proposition: 
P1: Post-conflict trials will lead to a stable and more durable peace in autocratic as well as democratic post-conflict societies.

\section{Non-Retributive Justice and Peace}

Truth commissions are a new type of institution that has developed in order to deal with past atrocities where trials have been ruled out or proven too limited. ${ }^{7}$ The focus is on victims and their stories of human rights violations (Gloppen, 2005: 27). Those skeptical toward retributive justice, such as Long \& Brecke (2003: 67), suggest that official truth telling may begin to heal social wounds by unmasking official lies and stripping away impunity. By identifying perpetrators and victims, truth commissions are also linked to the restoration of identity such that social and political roles are reshaped and social relations refined (Long \& Brecke, 2003: 68-69; Gibson \& Gouws, 1999; 2003; Gibson, 2002; 2004). Truth-telling may, at least, contribute to the opening of a national reconciliation process by allowing past atrocities to become a possible subject for future political action. ${ }^{8}$

Truth commissions are clearly associated with a peace based on reconciliation rather than repression and deterrence. Consequently, truth commissions, unless they are only attempts to cover up past atrocities, are primarily associated with post-conflict democratic societies, while of limited importance for maintaining peace and stability in post-conflict non-democratic regimes. We make the following proposition:

P2: Truth-telling through the establishment of truth commissions leads to a stable and more durable peace in post-conflict democratic societies.

An additional strategy of post-conflict reconciliation is to offer some reparation or compensation to victims and help them to recover from past brutality. Such reparations may entail economic compensation, provision of health service, symbolic restoration, public apologies, and efforts to advance social integration at the community level (Gloppen 2004: 18). Such efforts at

\footnotetext{
${ }^{7}$ According to Gloppen (2005: 28) the first major truth commission was established in Argentina in 1983, and by the turn of the century about 20 truth commissions had completed their work or were underway, most of them in Latin American and African countries.

${ }^{8}$ The relationship between truth commissions or truth telling and the pursuit of retributive justice has, however, been mixed. In some cases, truth telling has been short of justice, and amnesties have been offered for truth. In other cases,
} 
reconciliation stand in stark contrast to notions of retributive justice solely based on notions of punishment (Kalmanovitz, 2006). According to Gloppen (2004) the presumption is that the physical, psychological, and social damage caused by past injustice must be acknowledged and repaired before reconciliation can be accomplished. But as long as the purpose of the measure is reconciliation, not repression and deterrence of rebels, we should expect the influence of reparation to victims to be most important in post-conflict democratic regimes:

P3: Restitution of victims through material or symbolic reparations leads to a stable and durable peace in post-conflict democratic societies.

Purges constitute a fourth type of post-conflict action. Lustration or purges can be seen as retributive type of justice, because they lock former perpetrators and collaborators out of jobs and positions (Nalepa, 2006; Gloppen 2004). However, they may also be a forward looking strategy seen as part of an institutional reform. They form a break with the former regime. Purges and other types of institutional reforms should, therefore have a positive effect on the ability to restore lasting peaceful relations; regardless of whether the new regime is a democratic or more autocratic one. We make the following proposition:

P4: Purges in the administration lead to a stable or more durable peace in autocratic as well as democratic post-conflict societies.

\section{Amnesty and Exile}

In a number of post-conflict settings, some states have decided to ignore their past rather than to confront it. According to Gloppen (2005: 23) amnesty guarantees in the negotiation process may effectively block the recourse to prosecution. This argument is empirically supported by Long \& Brecke (2003: 71) finding the granting of amnesties to limit the realization of justice, though how severely depends on when in the reconciliation process it is granted. Amnesties may help perpetrators of "wrong-doing" during the conflict to avoid prosecution and thereby be able to launch into war once again. They may also increase the risk of wild justice or private revenge as

such as with the Nunca Mas report in Argentina, published 1985, the material was used for compensation to victims as well as trials against perpetrators of the previous military regime (Gloppen 2005; Long \& Brecke 2004). 
well as distort the more long-term process of reconciliation. We suggest the following proposition:

P5: When evidence of amnesties is recorded, this reduces the post-conflict peace period.

Another possibility for wrongdoers to avoid prosecution is to flee into exile. This is not necessarily something the post-conflict society applies as an explicate policy; as it often depends on the decision of the defeated belligerent and the willingness of another state to accept the person. Nonetheless, a post-conflict government may not necessarily try to prevent wrongdoers from fleeing the country and on some occasions the victorious party may actively expel its opponents. We are, nevertheless, somewhat ambivalent in our expectations regarding the effect of exile on the sustainability of peace. Exile means that wrongdoers are removed from the postconflict society, preventing attempts at private justice and preventing past wrongdoers from launching another attack from the inside, though they may still be able to gather forces for another attack and work as inspiration for those dissatisfied with the post-conflict regime. As with amnesty, it may also be an obstacle to reconciliation, as victims feel that the perpetrators are not properly punished for their past atrocities. On the other hand, banishment does convey a notion of

punishment. For purposes of constructing a clear proposition, given the lack of punishment and mechanisms for reconciliation, we elect to state our proposition as:

P6: When evidence of exile is recorded this reduces the length of the post-conflict peace period.

\section{Investigating the Influence of Post-Conflict Justice}

The Binningsbø, Elster \& Gates dataset on post-conflict justice (2005) offers a unique opportunity to empirically investigate our assumptions about PCJ on a large number of post-conflict cases, complementing the theoretical and case-study oriented research on PCJ with a large-N study. The dataset also allows us to distinguish between different types of PCJ in democratic and nondemocratic settings.

A society's ability to deal with its past by means of trials, purges, reparation to victims and truth commissions is heavily dependent upon characteristics and outcomes of the previous 
conflict as well as characteristics of the post-conflict society itself. We control for these factors in our analysis to determine whether different aspects of PCJ have an independent effect on postconflict peace or if peace as well as justice are products of the same underlying factors. ${ }^{9}$

The most important factor to look for in the transformation from autocracy to democracy is, according to de Brito, Gonzalez-Enriquez \& Aguilar, (2001: 3004-05), the balance of forces between the elite of the old regime and the groups favoring democratization. In transition by 'collapse' the opposition is not obliged to negotiate amnesty because the balance of power is far more favorable. Gloppen (2005: 23) presents a similar argument, when she suggests that prosecution is more likely to be deterred by the fear of increasing conflict in situations where the previous regime has retained significant support. Subsequently, we are more likely to see justice in situations where the previous regime has been severely defeated. Similarly, in the transition from war to peace, we should expect the balance of forces to be more decisive, making PCJ more likely, if the conflict is terminated by victory by the government or the opposition than if it is terminated by agreements, negotiations or cease-fire. Indeed, Binningsbø, Elster \& Gates (2005) find post-conflict trials to be strongly associated with victory. Of the 98 trials registered in the dataset, 68 took place following victory to side A or B. Also in those cases where conflicts end with victory, we find that amnesty and exile are not offered as a policy options in the majority of cases. The strong correlation between type of termination and commitment to some type of transitional justice makes it necessary to control for termination type in the analysis. Fortunately, the type of conflict termination is already coded into the Binningsbø, Elster \& Gates, (2005) dataset, making it easy to investigate if the various attempts at PCJ have an effect on peace duration when the conflicts' outcome is controlled for.

The duration of the previous regime is another factor emphasized by scholars of transitional justice (Elster 2004, de Brito, Gonzalez-Enriquez \& Aguilar 2001). According to Elster (2004: 120), there seems to be more transitional justice in situations where the previous

\footnotetext{
${ }^{9}$ Another potential problem when investigating the possible effect of post-conflict justice on peace duration is that these processes can eventually be a consequence rather than a cause of peace consolidation. For example, reparation to victims can be carried out when states come to terms with their troublesome past. Trials and purges are also more easily carried out when the post-conflict regime is no longer contested. Assuming that it takes some time before postconflict reconciliation is obtained; the longer it takes before post-conflict justice is carried out, thus more likely it is that justice is a consequence rather than a cause of the reconciliation process. In order to deal with this problem of endogeneity, we have, therefore, recorded only those processes of post-conflict justice taking place within a 10-year period after conflict termination, assuming that these processes are more likely to be a cause rather than a consequence of peace and reconciliation.
} 
regime has been of a relatively short duration, as the memories of suffering seems to be more vivid and the emotions correspondently strong. A long term dictatorship must also have acquired a minimum level of consensus among a significant part of the population and has been able to establish more routinized mechanisms of social control (de Brito, Gonzalez-Enriquez \& Aguilar, 2001: 309). Extending this logic to peace-building, we may also assume that long-lasting conflicts are less likely to result in PCJ, as both wrongdoers and victims may be more difficult to identify, and the emotions from suffering are less associated with particular acts or events. In the peacebuilding literature the findings have, however, been mixed, making our expectations regarding conflict-duration and transitional justice somewhat vague. Since the data we rely on allows us to control for the precise length of the conflict period, an analysis of the influence of conflict duration and transitional justice on peace can easily be conducted.

A third factor emphasized by scholars of democratization and transitional justice is the nature of the ideological preferences and the commitments of the new democratic forces or leadership (e.g. de Brito, Gonzalez-Enriquez \& Aguilar, 2001). Since the probability of sustainable peace might depend on regime type, and some types of PCJ are more common in democratic societies, post-conflict regime type will be controlled for in the analysis. In the second part of the analysis, the same data on regime type are used to distinguish between PCJ in democratic and non-democratic societies. We expect the influence of truth-commissions and reparation to victims, in particular, to be more important in post-conflict democratic societies.

A states' ability to carry out PCJ depends on the availability of institutional, human, and financial resources to carry out the processes of justice. More well-to-do states should, therefore, be better equipped for PCJ as well as peace, which is why we control for GDP/capita in the analyses.

\section{Method}

To analyze the duration of post-conflict peace we use a Cox proportional hazards model. The data for this analysis are structured as multiple-record data with multiple events with censoring. Given that civil wars frequently occur in the same country at different points in time, and indeed with the Uppsala-PRIO data, more than one armed civil conflict can occur contemporaneously, we must also account for a separate peace period after the resolution of conflict between 
belligerents. ${ }^{10}$ To account for the obvious non-independence of peace events we calculate robust standard errors. A number of wars and post-conflict peace periods were still on-going in 2003 (the last year of our data); we censored these cases.

\section{Data and operationalizations}

The Binningsbø, Elster \& Gates (2005) data provide an overview of how post-conflict societies deal/have dealt with the wrongdoings of their recent pasts. In order to define a 'post-conflict society' they rely on the Uppsala-PRIO armed conflict dataset (Gleditsch et al., 2002), which defines a conflict as 'a contested incompatibility that concerns government and/or territory where the use of armed force between two parties, of which at least one is the government of a state, results in at least 25 battle-related deaths' (Strand, Wilhelmsen \& Gleditsch, 2004: 3). ${ }^{11}$ To allow for time-varying covariates the dataset is disaggregated into 'peace years' for each individual post-conflict period. The first 'peace year' for each subject starts the first day of peace after conflict and ends 31st December the same year. Next 'peace year' starts 1st January the following year and ends 31st December, or the date the conflict resumes (failure). The subject enters the dataset again the first day of peace after (if) the resumed conflict ends. Post-conflict peace periods that did not fail (no resumed conflict) before the last day of observation in the dataset (31 December 2003) are right-censored. Begin and end dates of the conflicts and peace transition periods are based on Gates \& Strand's (2004) event dataset. Following Gates \& Strand (2004: 10), 'Our initial coding criteria only includes the periods from when a conflict reaches 25 fatalities to the last fatality in the last year of recorded conflict.' However, a conflict period must have been followed by at least two years without observation of violence in order to be defined terminated. A conflict is not reported to have terminated if there is only one year without observation of violence between two years of violence - this is one continuous conflict period. The final analyses include 200 post-conflict societies with 1130206 days at risk of failure (3191 'peace years'). Ninety-three failures occur. ${ }^{12}$

\footnotetext{
${ }^{10}$ In the Binningsbø, Elster \& Gates (2005) dataset there are 291 conflict periods, of which, 105 reoccur, indicating a relatively high risk of peace failure.

${ }^{11}$ Version 3.0 (December 2004).

${ }^{12}$ Due to missing data quite a few 'peace years' are missing, the time period under investigation consists of 3920 'peace years' in total.
} 


\section{Dependent variable:}

To be able to investigate post-conflict peace duration, two conflict-related variables were added to the existing dataset: A duration variable measuring the length of the post-conflict peace period. This variable is measured in days, and represents the number of days from the first day of peace to the first day when the conflict again crosses the 25 battle-related deaths threshold. If the conflict does not re-occur, the end date is set to December 31, 2003, which is the last date in the dataset. An additional event variable (censor) indicates whether or not the 'peace year' ends in another conflict. The censoring variable is coded 1 if the 'peace year' ends in resumed conflict (failure) and zero if it did not.

Independent variables:

Our main independent variables reflect to what extent post-conflict societies deal with crimes committed during the conflict. The main sources for this information are Keesing's Record of World Events, Library of Congress Country Studies, Minorities at Risk Assessments and Chronologies, and the Peace Agreements and Truth Commissions Digital Collection from the United States Institute for Peace. Other sources were used additionally. See Binningsbø (2005) for detailed narratives and references. Altogether, the dataset provides indicators of 4 types of PCJ: trials, purges, truth commissions, and reparations to victims, and 2 indicators associated with abstaining from post-conflict justice: amnesty and exile. ${ }^{13}$

The detailed information in the Binningsbø, Elster \& Gates dataset allows us to create additional variables based on various combinations in the data material. We run our analysis on an aggregation of each of these types of post-conflict justice. For the purposes of our analysis, we created a dummy variable indicating whether or not a particular type of transitional justice was employed. ${ }^{14}$ We also include two variables indicating whether or not states have abstained from PCJ through exile or amnesty.

\footnotetext{
13 In the Binningsbø, Elster, \& Gates (2005) dataset, all variables are measured due to which side of the conflict is the subject of justice, i.e. the government side (side A) or the opposition side (side B), or both, defined by the situation when the conflict started. We do not designate them as such so as to capture as much variance as possible.

${ }^{14}$ In addition to looking at the different types of post-conflict justice separately, coded 1 if there has been postconflict justice and 0 otherwise; we created an additive index measuring the degree of post-conflict justice, based on how many types of justice have been conducted in the post-conflict society. Since there are four types of post-conflict justice, this variable will have values from 0 to 4 , where 0 is no efforts toward justice and 4 if evidence of all 4 types is found. We also created an additive index of all recorded PCJ-measures, regardless of whether they were postconflict justice or abstaining from justice efforts.
} 
Control variables:

As discussed above, the variable that is, perhaps, most likely to influence the probability of postconflict justice as well as the likelihood of future conflict is the balance of forces after conflict, indicated by the type of conflict settlement. We created 2 dummy variables: victory (which includes both victory by sides A and B) and negotiated agreement or cease-fire. ${ }^{15}$ The reference category is low activity and unclear terminations.

Another important control variable is the length of the conflict prior to the post-conflict peace period. This variable counts the number of days the conflict lasted, from the first day it reached the 25 annual battle-deaths threshold to the last day of violence.

To measure post-conflict regime type we rely on information from the Polity Project's Dataset (Marshall 2003). We use the Polity2 variable, a democracy-autocracy scale where a county's autocracy score is subtracted from its democracy score. It ranges from -10, perfectly autocratic, to +10 , fully democratic. In the second part of the analysis, we seek to distinguish between democratic and non-democratic post-conflict societies. In doing so, we set the threshold for being democratic at 5 . All 'peace years' with a polity score above 4.9 are considered to be democratic.

We believe type of conflict matters. Therefore we include a variable controlling for the incompatibility over which the conflict was fought. This is a dummy where the value 1 corresponds to conflicts over territory; the reference category is governmental conflicts. In this way we can differentiate secessionist wars and those conflicts for which the objective is to capture the state for ideological or narrower interests.

The intensity of conflict might also be important regarding post-conflict peace duration. The battle-deaths data are from Lacina \& Gleditsch (2005), the variable is a natural logtransformed.

We have also controlled for economic variables. Our GDP per capita data is based on GDP data from Fearon \& Laitin (2003), but has been updated by Lujala (2006) to 2002 using economic data from Penn World Tables 6.0.

\footnotetext{
${ }^{15}$ About 20 conflict periods ended by independence for side B, thereby creating a new independent state. Most of these are colonial conflicts were the colony gained its independence, creating long peace periods with no risk of conflict reoccurrence. These 20 cases were therefore removed from the analysis, although they did not have strong effects on the final results.
} 


\section{Results}

Table 1 presents the regression results for the full sample of post-conflict periods, meaning that autocratic as well as democratic post-conflict periods are included. Models 1-3 and Models 4-6 represent different measures of PCJ. We first investigate the effect of the various types of PCJ separately. Based on the idea that it may be the "complete package” of PCJ that matters, i.e. that the more types of justice are applied thus more likely one would be to obtain durable peace, an additive index of the four types of justice (trials, purges, reparation to victims, truth commissions), is constructed and the results presented in Model 2 and 5. In Model 3 and 6 this additive index is supplemented by amnesty and exile to test the idea that it can be beneficial to address the past rather than ignoring it, also if this includes granting amnesty and allowing for exile. Perhaps providing amnesty and allowing perpetrators to flee into exile may lead to more durable peace even though it prevents some trials from taking place.

Furthermore, we expect theoretically that the type of conflict termination does have important influence on post-conflict peace duration. Victory by either side is expected to lead to a significantly longer peace period than conflict terminating by other means. At the same time we know that approximately $70 \%$ of the post-conflict trials reported in the post-conflict data take place following a clear victory to either side. When controlling for conflict termination in the model, the manner in which the conflict ended can, therefore, be expected to dominate the statistical effects of PCJ measures on peace duration. As an experiment we therefore removed conflict termination in Models 4-6, repeating the analysis from Models 1-3.

From Table 1 we can see that victory is the variable that appears strongest and most consistent in the explanation of peace duration, while none of the post-conflict justice variables have significant influence. However, the signs of the PCJ-coefficients suggest that most types of PCJ prolong peace, but the relationships are weak and insignificant. Adding the various types of PCJ together in Models 2 and 3 do not produce significant improvement in our results. From Models 1 to 3, we can therefore conclude that most PCJ efforts appear to be working in the correct direction but the effects are weak and insignificant.

In Models 4 to 6, conflict termination was removed from the equation, improving the effect of trials on peace duration. The signs of the PCJ coefficients remain and the effect of trials becomes significant. When testing the effects of the additive PCJ indexes (Total PCJ efforts) in Model 5 this has a significant and positive influence on the duration of peace, and the variable 
remains significant when amnesty and exile are added to this index in Model 6. In conclusion, the results from Models 1 to 6, Table 1, indicate that the duration of post-conflict peace depends upon how the conflict is terminated. Processes of PCJ may contribute to peace duration, but the results are weak and inconsistent. Trial appears to be the most important type of justice, though the effect of trials is truly sensitive to conflict termination. The other interesting finding is that amnesty reduces peace duration, but as with trials, the effect of this variable is also sensitive to conflict termination, indicating that conflict termination clearly affects the prospect for justice as well as post-conflict peace duration.

The importance of trials for the duration of post-conflict peace, in general, is somewhat in line with our theoretical expectations, since we expected trials to work both as a deterring factor in autocratic regimes and as a mean to reach reconciliation in post-conflict democratic societies. Other types of PCJ, such as reparations to victims and truth commissions were expected to be more influential in post-conflict democratic societies. In Table 2 we therefore include postconflict democratic societies only, although this lead to a significant reduction in the number of cases. $^{16}$

The results for democracies differ somewhat from those obtained for all cases in Table 2. Post-conflict trials appear to have a negligible effect in post-conflict democratic societies while purges still have a limited effect. In line with our theoretical expectations, the effect of nonretributive forms of justice is stronger in post-conflict democratic societies than in the general sample. Reparations to victims have a significant negative effect, while the effect of truth commission disappears due to discrimination. Of the 27 'peace years' with truth commissions in the sample, none experience a relapse into violence. Moreover, amnesty has a strong positive effect on peace failure in post-conflict democratic societies, while exile still appears to prolong peace. The combined indexes do not have the same effect among post-conflict democratic societies as they do when all cases are included. If we compare the results in Table 2 to the results in Table 1, we can see that the effects of various types of post-conflict justice appear less sensitive to conflict termination type in post-conflict democratic societies. The results presented in Table 2 indicate that at least some of our theoretical expectations seem to hold; non-retributive forms of post-conflict justice appear to prolong peace duration in democratic societies, although the effect of retributive justice in the form of trials is weak.

\footnotetext{
${ }^{16}$ Since Table 2 includes post-conflict democratic societies only, the variable measuring regime type is not included.
} 
How do the results obtained in Tables 1 and 2 fit with our initial theoretical propositions? The first proposition suggested that trials would lead to longer peace duration in democratic as well as non-democratic societies. Trials appear to prolong peace in democratic as well as nondemocratic post-conflict societies, but the results are weak, and appear sensitive to conflict termination. The second proposition suggested that reparation to victims would prolong peace in post-conflict democratic societies. Reparation to victims has a negative effect on peace failure in democratic as well as non-democratic societies, but the effect of this variable is significant only in post-conflict democratic societies. The results on reparation to victims, therefore, fit nicely with our theoretical assumptions. The third proposition suggested that truth commissions would lead to longer peace duration in democratic societies. Truth commissions have a negligible effect on post-conflict peace duration in general, but the relationship is quite strong for post-conflict democratic societies, however, due to discrimination the strong effect is not significant. Nonetheless, we interpret this as support for the third theoretical proposition. The fourth proposition regarding purges is not supported. Purges appear to have a negligible effect on peace duration in democratic as well as non-democratic societies. Our fifth proposition was made about amnesty, and we expected amnesties to reduce rather than prolong the post-conflict peace period. In fact, amnesty appears to reduce peace duration in most post-conflict settings, but the effect is stronger for democracies than for the general sample. Still, we find some support for our fifth proposition. Finally, though we were ambivalent about our sixth proposition, we stated that exile reduces the post-conflict peace period. In all models, however, exile contributes to prolonging peace duration, and in many of our models, this relationship is strong and significant, lending no support to the final proposition.

A number of our propositions are somewhat supported, but for many of these variables the results are weak and rarely significant. For the general sample, the influence of justice is sensitive to conflict termination, indicating that termination type is more important than justice. However, non-retributive forms of post-conflict justice, such as reparation to victims and truth commissions appear to prolong peace in post-conflict societies. A result that appears strong and consistent also when controlling for conflict termination.

A number of factors may account for our failure to obtain strong and consistent results. How societies deal with past atrocities may simply be irrelevant for the duration of peace. Other factors, such as the type of conflict termination, post-conflict regime characteristics, and the 
severity and length of the conflict, might be more important. We have already indicated that conflict termination type is important and that processes of PCJ are sensitive to termination, but most of the other control variables do not obtain strong and consistent results across the various models. We should also keep in mind that although the results are weak and generally insignificant, the directions of the coefficients are largely consistent across the various models and, though there are exceptions, they are mostly in line with our theoretical propositions. A relatively low $\mathrm{N}$, particularly when studying the post-conflict democratic societies only, makes it more difficult to obtain significant results. It may also be that the categorization of PCJ into a limited set of typologies generalizes more case-specific events too broadly. The variation between different types of justice within different political and cultural contexts may, still, be too great to obtain strong and consistent large- $\mathrm{N}$ results. The context in which PCJ takes place as well as the character and intention of this justice should therefore be more carefully explored in future research. $^{17}$

\section{Conclusion}

We expected various forms of PCJ (trials, purges, reparation to victims, and truth commissions) to have positive influence on post-conflict peace duration. Processes associated with abstaining from PCJ (amnesty and exile), in contrast, we expected to be negatively associated with peace duration. However, we find only partial support for our theoretical propositions. The most important finding seems to be that trials contribute to peace duration, but the results are weak and sensitive to how the conflict terminated. Conflicts terminating by victory increase the chances of trials and prolong the peace period, though this finding is somewhat weaker when we look at post-conflict democratic societies only. For the other types of PCJ, when investigated on the general sample, the results were weak and insignificant. However, non-retributive forms of PCJ, such as reparation to victims and truth commissions, have a prolonging effect on the duration of peace in post-conflict democratic societies. Also, as shown above in our analyses, exile significantly reduces the risk of peace failure. Amnesty, on the other hand, does in most models significantly increase the risk of peace failure.

\footnotetext{
${ }^{17}$ We also plan to explore patterns of non-proportionality in more detail and estimate models controlling for these irregularities. To investigate the assumptions of non-proportionality more carefully, we re-ran our analysis investigating the hazard rate for the first 10 and 20 years after conflict termination. The idea was that the effect of the various types of justice could be different over a 10 -year period than a 20 -year period. However, the results that we obtained from these analyses were not significantly different from the results presented in this paper.
} 
Retributive measures are not robustly statistically significant across analyses. The processes of democratization associated with transitional justice and post-conflict justice provide an environment in which a focus on the victim is especially effective in sustaining peace in the shadow of war. Where transitional justice and post-conflict justice are one in the same, this effect is particularly evident. 


\section{References}

Aguilar, Paloma. 2001. 'Justice, Politics and Memory in Spanish Transition’, in de Brito, Alexandra Barahona, Carmen Gonzalez-Enriquez, \& Paloma Aguilar (eds.), 2001. The Politics of Memory: Transitional Justice in Democratizing Societies. Oxford: Oxford University Press: 92-118.

Aron, Raymond, 1981. Peace and War: A Theory of International Relations, Garden City, NY: Doubleday \& Company.

Bass, Gary J., 2005. 'Managing Amnesty’, Paper presented at the 'Transitional Justice and Civil War Settlements’ workshop in Bogotá, Colombia 18-19 October 2005.

Bass, Gary J., 2004. 'Jus Post Bellum', in Philosophy and Public Affairs 32(4): 384-412.

Binningsbø, Helga Malmin, 2006. “Power-Sharing and Postconflict Peace Periods”, paper prepared for presentation at the $47^{\text {th }}$ Annual Convention of the International Studies Association, San Diego, California.

Binningsbø, Helga Malmin, Jon Elster \& Scott Gates, 2005. 'Civil War and Transitional Justice, 1946-2003: A Dataset', Paper presented at the 'Transitional Justice and Civil War Settlements’ workshop in Bogotá, Colombia 18-19 October 2005.

Binningsbø, Helga Malmin, 2005. 'The Civil War and Transitional Justice Dataset. Background Narratives', Centre for the Study of Civil War, PRIO.

Dudley, Steven. 2006. 'Colombia’s Amnesty for Paramilitary Groups Comes Under Fire’. The Miami Herald, February $15^{\text {th }}$.

de Brito, Alexandra Barahona, Carmen Gonzalez-Enriquez, \& Paloma Aguilar (eds.), 2001. The Politics of Memory: Transitional Justice in Democratizing Societies. Oxford: Oxford University Press.

Elster, Jon, 2005. 'Transitional Justice and Political Violence', Paper presented at the

‘Transitional Justice and Civil War Settlements’ workshop in Bogotá, Colombia 18-19 October 2005.

Elster, Jon, 2004. Closing the Books: Transitional Justice in Historical Perspective. Cambridge: Cambridge University Press.

Encyclopædia Britannica Online: http://search.eb.com/

Fearon, James D. 2005. 'Comments on the Ex Ante/Ex Post Problem in Transitional Justice', Paper presented at the 'Transitional Justice and Civil War Settlements' workshop in Bogotá, Colombia 18-19 October 2005.

Fletcher, Laurel L. \& Harvey M. Weinstein. 2002. 'Violence and Social Repair: Rethinking the Contribution of Justice to Reconciliation. Human Rights Quarterly, 24 (3): 573-639. 
Galtung, Johan, 1985. 'Twenty-Five Years of Peace Research: Ten Challenges and Some Responses', in Journal of Peace Research 22(2): 141-158.

Gates, Scott, Håvard Hegre, Mark Jones, \& Håvard Strand. 2006. “Institutional Inconsistency and Political Instability: Polity Duration, 1800-2000”. American Journal of Political Science 50(4) (November 2006) (in press).

Gates, Scott \& Håvard Strand, 2004. 'Modeling the Duration of Civil Wars: Measurement and Estimation Issues'. Paper presented at the 2004 Meeting of the Standing Group on International Relations, the Hague September 9-11.

Gibson, James L. 2002. 'Truth, justice and reconciliation: Judging the fairness of amnesty in South Africa', American Journal of Political Science 46 (3): 540-556.

Gibson, James L. 2004. Overcoming apartheid: Can truth reconcile a divided nation? New York: Russell Sage Foundation.

Gibson, James L. and Amanda Gouws. 1999. 'Truth and Reconciliation in South Africa: Attributions of Blame and the Struggle over Apartheid', American Political Science Review 93(3): 501-517.

Gibson, James L. and Amanda Gouws. 2003. Overcoming Intolerance in South Africa. Experiments in Democratic Persuasion. Cambridge Studies in Public Opinion and Political Psychology, Cambridge: Cambridge University Press.

Gleditsch, Nils Petter, Peter Wallensteen, Mikael Eriksson, Margareta Sollenberg, \& Håvard Strand. 2002. 'Armed Conflict 1946-2001: A New Dataset', Journal of Peace Research 39 (5):615-637.

Gloppen, Siri, 2005. 'Roads to Reconciliation: A Conceptual Framework', in Elin Skar, Siri Gloppen \& Astrid Suhrke eds. Roads to Reconciliation, Lexington Books: Lanham: 17-50. Goodman, Joshua. 2006. 'UN Urges Columbia to Hold Paramilitary Groups Accountable for Human Right Abuses’. Associated Press Worldstream, Februray 13.

Kaminski, Marek M. and Monika Nalepa. 2006. 'Judging Transitional Justice: A New Criterion For Evaluating Truth Revelation Procedures’, Journal of Conflict Resolution, 50(3): 383408.

Keesings Record of World Events: www.keesings.com

Huntington, Samuel P., 1993. The Third Wave: Democratization in the Late Twentieth Century. Oklahoma: University of Oklahoma Press.

Kalmanovitz, Pablo. 2006. 'Responsibility and Liability after Civil Conflicts'. Paper presented at the Centre for the Study of Civil War, PRIO. Oslo, June 28, 2006

Lacina, Bethany \& Nils Petter Gleditsch, 2005. 'Monitoring Trends in Global Combat: A New Dataset of Battle Deaths', European Journal of Population 21(2-3): 145-166.

Library of Congress Country Studies: http://lcweb2.loc.gov/frd/cs/cshome.html 
Long William J. \& Peter Brecke, 2003. War and Reconciliation: Reason and Emotions in Conflict Resolution. Cambridge: MIT Press.

Lujala, Päivi, 2006. 'The Spoils of Nature: Armed Civil Conflict and Rebel Access to Natural Resources', Unpublished manuscript, NTNU.

Mani, Rama, 2002. Beyond Retribution: Seeking Justice in the Shadow of War. Cambridge, UK: Blackwell Publishers.

Marshall, Monty G., 2003. Polity IV Project. http:/www.cidcm.umd.edu./inscr/polity/ (Last updated August $10^{\text {th }} 2005$, last accessed March $\left.8^{\text {th }}, 2006\right)$.

McAdams, James, 1997. Transitional Justice and the Rule of Law in New Democracies. Notre Dame: Notre Dame Press.

Minow, Martha, 1999. Between Vengeance and Forgiveness: Facing History after Genocide and Mass Violence, Boston: Beacon Press.

Minorities at Risk (MAR) Project, Assessments and Chronologies: http://www.cidcm.umd.edu/inscr/mar/data.asp

Molinski, Dan, 2005. 'Colombian Village Scared by Paramilitary Violence Choose Peace Over Justice’, Associated Press Worldstream July $14^{\text {th }}$.

Nalepa, Monika, 2006. 'The Road to Reconciliation: Avoiding False Conviction and False Acquittal'. Paper prepared for presentation at the American Political Science Association Meeting, Philadelphia, PA, August 31-September3, 2006.

Othman, Mohamed, 2005. 'Justice and Reconciliation', in Elin Skaar, Siri Gloppen \& Astri Suhrke eds. Roads to Reconciliation, Lexington Books: Lanham: 249-270.

Pankhurst, Donna, 1999. 'Issues of Justice and Reconciliation in Complex Political Emergencies: Conceptualizing Reconciliation, Justice and Peace’, Third World Quarterly 20(1): 239256.

Pinto, Antonio Costa. 2001. 'Settling Account with the Past in a Troubled Transition to Democracy', in De Brito, Alexandra Barahona, Carmen Gonzalez-Enriquez, \& Paloma Aguilar (eds.), 2001. The Politics of Memory: Transitional Justice in Democratizing Societies. Oxford: Oxford University Press: 65-91.

Reyntjens, Filip \& Stef Vandeginste. 2004. 'Rwanda: A Typical Transition', in Elin Skar, Siri Gloppen \& Astrid Suhrke eds. Roads to Reconciliation, Lexington Books: Lanham: 101128.

Shraga, Daphna. 2004. 'The Second Generation UN-Based Tribunals: A Diversity of Mixed Jurisdiction', in Elin Skar, Siri Gloppen \& Astrid Suhrke eds. Roads to Reconciliation, Lexington Books: Lanham: 55-82. 
Sikkink, Kathryn \& Carrie Booth Walling, 2005. 'Errors about Trials: The Political Reality of the Justice Cascade and Its Impact', paper presented at the Annual Meeting of the American Political Science Association, August 31--September 3, Washington, DC.

Skaar, Elin. 2004. 'Argentina: Truth, Justice and Reconciliation', in Elin Skar, Siri Gloppen \& Astrid Suhrke eds. Roads to Reconciliation, Lexington Books: Lanham: 157-176.

Skaar, Elin, Siri Gloppen \& Astri Suhrke eds.. 2004. Roads to Reconciliation, Lexington Books: Lanham.

Stover, Eric. 2005: The Witnesses: War Crimes and the Promise of Justice in The Hague. University of Pennsylvania Press.

Stover, Eric \& Harvey M. Weinstein, eds. 2005. My Neighbor, My Enemy: Justice in the Aftermath of Mass Atrocity. Cambridge: Cambridge University Press.

Strand, Håvard, Lars Wilhelmsen \& Nils Petter Gleditsch, 2004: Armed Conflict Dataset Codebook. Version 3.0, 7 December 2004.

United States Institute for Peace, Peace Agreements Digital Collection: http://www.usip.org/library/pa.html

United States Institute for Peace, Truth Commissions Digital Collection: http://www.usip.org/library/truth.html

Uppsala Conflict Database: http://www.pcr.uu.se/database/index.php 


\begin{tabular}{|c|c|c|c|c|c|c|}
\hline & (1) & (2) & (3) & (4) & (5) & (6) \\
\hline & & & & & & \\
\hline Trial & $\begin{array}{l}-0.320 \\
(0.292)\end{array}$ & & & $\begin{array}{l}-0.561 \\
(0.055) *\end{array}$ & & \\
\hline Purge & $\begin{array}{l}0.116 \\
(0.786)\end{array}$ & & & $\begin{array}{l}-0.010 \\
(0.981)\end{array}$ & & \\
\hline Reparation to victims & $\begin{array}{l}-0.397 \\
(0.316)\end{array}$ & & & $\begin{array}{l}-0.325 \\
(0.416)\end{array}$ & & \\
\hline Truth commission & $\begin{array}{l}-0.502 \\
(0.699)\end{array}$ & & & $\begin{array}{l}-0.220 \\
(0.857)\end{array}$ & & \\
\hline Total PCJ efforts & & $\begin{array}{l}-0.239 \\
(0.226)\end{array}$ & & & $\begin{array}{l}-0.361 \\
(0.062)^{*}\end{array}$ & \\
\hline Amnesty & $\begin{array}{l}0.305 \\
(0.213)\end{array}$ & $\begin{array}{l}0.272 \\
(0.224)\end{array}$ & & $\begin{array}{l}0.365 \\
(0.129)\end{array}$ & $\begin{array}{l}0.299 \\
(0.163)\end{array}$ & \\
\hline Exile & $\begin{array}{l}-0.248 \\
(0.318)\end{array}$ & $\begin{array}{l}-0.235 \\
(0.326)\end{array}$ & & $\begin{array}{l}-0.456 \\
(0.055)^{*}\end{array}$ & $\begin{array}{l}-0.450 \\
(0.051)^{*}\end{array}$ & \\
\hline Total dealing efforts & & & $\begin{array}{l}-0.062 \\
(0.528)\end{array}$ & & & $\begin{array}{l}-0.170 \\
(0.074) *\end{array}$ \\
\hline Victory & $\begin{array}{l}-0.761 \\
(0.027)^{* *}\end{array}$ & $\begin{array}{l}-0.755 \\
(0.031)^{* *}\end{array}$ & $\begin{array}{l}-0.824 \\
(0.018)^{* *}\end{array}$ & & & \\
\hline Negotiated Settlement & $\begin{array}{l}0.074 \\
(0.856)\end{array}$ & $\begin{array}{l}0.026 \\
(0.949)\end{array}$ & $\begin{array}{l}0.051 \\
(0.898)\end{array}$ & & & \\
\hline Territorial conflict & $\begin{array}{l}-0.439 \\
(0.056)^{*}\end{array}$ & $\begin{array}{l}-0.454 \\
(0.035)^{* *}\end{array}$ & $\begin{array}{l}-0.436 \\
(0.040)^{* *}\end{array}$ & $\begin{array}{l}-0.451 \\
(0.060)^{*}\end{array}$ & $\begin{array}{l}-0.445 \\
(0.052)^{*}\end{array}$ & $\begin{array}{l}-0.472 \\
(0.041)^{* *}\end{array}$ \\
\hline Conflict duration (ln) & $\begin{array}{l}0.035 \\
(0.436)\end{array}$ & $\begin{array}{l}0.031 \\
(0.494)\end{array}$ & $\begin{array}{l}0.042 \\
(0.362)\end{array}$ & $\begin{array}{l}0.064 \\
(0.101)\end{array}$ & $\begin{array}{l}0.062 \\
(0.122)\end{array}$ & $\begin{array}{l}0.082 \\
(0.039)^{* *}\end{array}$ \\
\hline Battle deaths (ln) & $\begin{array}{l}-0.068 \\
(0.098)^{*}\end{array}$ & $\begin{array}{l}-0.057 \\
(0.176)\end{array}$ & $\begin{array}{l}-0.062 \\
(0.148)\end{array}$ & $\begin{array}{l}-\mathbf{0 . 0 7 7} \\
(\mathbf{0 . 0 5 6})^{*}\end{array}$ & $\begin{array}{l}-0.056 \\
(0.172)\end{array}$ & $\begin{array}{l}-0.064 \\
(0.135)\end{array}$ \\
\hline Political regime & $\begin{array}{l}-0.028 \\
(0.178)\end{array}$ & $\begin{array}{l}-0.029 \\
(0.158)\end{array}$ & $\begin{array}{l}-0.026 \\
(0.194)\end{array}$ & $\begin{array}{l}-0.023 \\
(0.198)\end{array}$ & $\begin{array}{l}-0.023 \\
(0.197)\end{array}$ & $\begin{array}{l}-0.018 \\
(0.286)\end{array}$ \\
\hline GDP per capita ${ }^{\#}(\ln )$ & $\begin{array}{l}-0.141 \\
(0.310)\end{array}$ & $\begin{array}{l}-0.152 \\
(0.271) \\
\end{array}$ & $\begin{array}{l}-0.169 \\
(0.221)\end{array}$ & $\begin{array}{l}-0.117 \\
(0.408)\end{array}$ & $\begin{array}{l}-0.127 \\
(0.372) \\
\end{array}$ & $\begin{array}{l}-0.137 \\
(0.344) \\
\end{array}$ \\
\hline Time at risk & 1130206 & 1130206 & 1130206 & 1130206 & 1130206 & 1130206 \\
\hline Subjects & 200 & 200 & 200 & 200 & 200 & 200 \\
\hline Failures & 93 & 93 & 93 & 93 & 93 & 93 \\
\hline Countries & 86 & 86 & 86 & 86 & 86 & 86 \\
\hline 'Peace years' & 3191 & 3191 & 3191 & 3191 & 3191 & 3191 \\
\hline
\end{tabular}

Robust p values in parentheses

* significant at $10 \%$; ** significant at $5 \%$; *** significant at $1 \%$

\# in 1000s, lagged one year 
Table 2 Cox proportional hazard model with and without termination type, only democracies.

\begin{tabular}{|c|c|c|c|c|c|c|}
\hline & (1) & (2) & (3) & (4) & (5) & (6) \\
\hline & $\_\mathrm{t}$ & . $\mathrm{t}$ & & & & \\
\hline Trial & $\begin{array}{l}-1.166 \\
(0.422)\end{array}$ & & & $\begin{array}{l}-0.625 \\
(0.547)\end{array}$ & & \\
\hline Purge & $\begin{array}{l}1.643 \\
(0.280)\end{array}$ & & & $\begin{array}{l}1.542 \\
(0.229)\end{array}$ & & \\
\hline Reparation to victims & $\begin{array}{l}-2.851 \\
(0.081)^{*}\end{array}$ & & & $\begin{array}{l}-2.152 \\
(0.062) *\end{array}$ & & \\
\hline Truth commission & $\begin{array}{l}-41.031 \\
\text { (.) }\end{array}$ & & & $\begin{array}{l}-42.069 \\
(.)\end{array}$ & & \\
\hline Total PCJ efforts & & $\begin{array}{l}-0.637 \\
(0.497)\end{array}$ & & & $\begin{array}{l}-0.513 \\
(0.525)\end{array}$ & \\
\hline Amnesty & $\begin{array}{l}1.656 \\
(0.008) * * *\end{array}$ & $\begin{array}{l}1.410 \\
(0.009) * * *\end{array}$ & & $\begin{array}{l}1.091 \\
(0.023)^{* *}\end{array}$ & $\begin{array}{l}1.010 \\
(0.029)^{* *}\end{array}$ & \\
\hline Exile & $\begin{array}{l}-2.902 \\
(0.141)\end{array}$ & $\begin{array}{l}-2.296 \\
(0.112)\end{array}$ & & $\begin{array}{l}-2.398 \\
(0.160)\end{array}$ & $\begin{array}{l}-1.974 \\
(0.158)\end{array}$ & \\
\hline Total dealing efforts & & & $\begin{array}{l}-0.100 \\
(0.776)\end{array}$ & & & $\begin{array}{l}-0.133 \\
(0.723)\end{array}$ \\
\hline Victory & $\begin{array}{l}0.401 \\
(0.478)\end{array}$ & $\begin{array}{l}0.162 \\
(0.783)\end{array}$ & $\begin{array}{l}-0.331 \\
(0.580)\end{array}$ & & & \\
\hline Negotiated Settlement & $\begin{array}{l}-1.509 \\
(0.085)^{*}\end{array}$ & $\begin{array}{l}-1.311 \\
(0.042) * *\end{array}$ & $\begin{array}{l}-0.650 \\
(0.242)\end{array}$ & & & \\
\hline Territorial conflict & $\begin{array}{l}2.556 \\
(0.000) * * *\end{array}$ & $\begin{array}{l}2.042 \\
(0.003) * * *\end{array}$ & $\begin{array}{l}1.313 \\
(0.044)^{* *}\end{array}$ & $\begin{array}{l}2.209 \\
(0.010)^{* *}\end{array}$ & $\begin{array}{l}1.762 \\
(0.020)^{* *}\end{array}$ & $\begin{array}{l}1.341 \\
(0.026)^{* *}\end{array}$ \\
\hline Conflict duration (ln) & $\begin{array}{l}0.197 \\
(0.169)\end{array}$ & $\begin{array}{l}0.133 \\
(0.259)\end{array}$ & $\begin{array}{l}0.125 \\
(0.355)\end{array}$ & $\begin{array}{l}0.186 \\
(0.149)\end{array}$ & $\begin{array}{l}0.141 \\
(0.239)\end{array}$ & $\begin{array}{l}0.135 \\
(0.324)\end{array}$ \\
\hline Battle deaths (ln) & $\begin{array}{l}-0.556 \\
(0.024)^{* *}\end{array}$ & $\begin{array}{l}-0.362 \\
(0.055) *\end{array}$ & $\begin{array}{l}-0.459 \\
(0.003)^{* * *}\end{array}$ & $\begin{array}{l}-0.495 \\
(0.015)^{* *}\end{array}$ & $\begin{array}{l}-0.392 \\
(0.013)^{* *}\end{array}$ & $\begin{array}{l}-0.496 \\
(0.001) * * *\end{array}$ \\
\hline GDP per capita ${ }^{\#}$ (ln) & $\begin{array}{l}0.129 \\
(0.675)\end{array}$ & $\begin{array}{l}-0.174 \\
(0.632)\end{array}$ & $\begin{array}{l}-0.074 \\
(0.780)\end{array}$ & $\begin{array}{l}0.204 \\
(0.443)\end{array}$ & $\begin{array}{l}-0.046 \\
(0.883)\end{array}$ & $\begin{array}{l}-0.004 \\
(0.988)\end{array}$ \\
\hline Time at risk & 299804 & 299804 & 299804 & 299804 & 299804 & 299804 \\
\hline Subjects & 87 & 87 & 87 & 87 & 87 & 87 \\
\hline Failures & 16 & 16 & 16 & 16 & 16 & 16 \\
\hline Countries & 52 & 52 & 52 & 52 & 52 & 52 \\
\hline Observations & 842 & 842 & 842 & 842 & 842 & 842 \\
\hline
\end{tabular}

Robust $\mathrm{p}$ values in parentheses

* significant at $10 \%$; ** significant at $5 \%$; *** significant at $1 \%$

\# in 1000s, lagged one year 